\title{
Bacterial Cellulose: Production, Characterization, and Application as Antimicrobial Agent
}

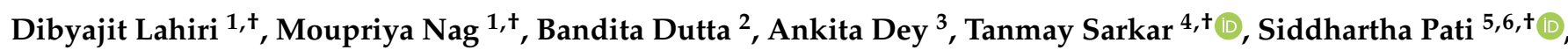
Hisham Atan Edinur ${ }^{7} \mathbb{D}$, Zulhisyam Abdul Kari ${ }^{8}{ }^{\mathbb{D}}$, Noor Haslina Mohd Noor ${ }^{9, *}$ and Rina Rani Ray ${ }^{2, *}$

check for

updates

Citation: Lahiri, D.; Nag, M.; Dutta, B.; Dey, A.; Sarkar, T.; Pati, S.; Edinur, H.A.; Abdul Kari, Z.; Mohd Noor, N.H.; Ray, R.R. Bacterial Cellulose: Production, Characterization, and Application as Antimicrobial Agent. Int. J. Mol. Sci. 2021, 22, 12984. https://doi.org/10.3390/ ijms222312984

Academic Editor: Jintae Lee

Received: 13 November 2021 Accepted: 29 November 2021 Published: 30 November 2021

Publisher's Note: MDPI stays neutral with regard to jurisdictional claims in published maps and institutional affiliations.

Copyright: (c) 2021 by the authors. Licensee MDPI, Basel, Switzerland. This article is an open access article distributed under the terms and conditions of the Creative Commons Attribution (CC BY) license (https:// creativecommons.org/licenses/by/ $4.0 /)$.
1 Department of Biotechnology, University of Engineering \& Management, Kolkata 700156, West Bengal, India; dibyajit.lahiri@uem.edu.in (D.L.); moupriya.nag@uem.edu.in (M.N.)

2 Department of Biotechnology, Maulana Abul Kalam Azad University of Technology, Haringhata 700156, West Bengal, India; bandita2611@gmail.com

3 Department of Pathology, Belle Vue Clinic, Kolkata 700156, West Bengal, India; ankita.dey16061996@gmail.com

4 Malda Polytechnic, West Bengal State Council of Technical Education, Government of West Bengal, Malda 732102, West Bengal, India; tanmays468@gmail.com

5 Skills Innovation \& Academic Network (SIAN) Institute, Balasore 756001, Odisha, India; patisiddhartha@gmail.com

6 NatNov Bioscience Private Limited, Balasore 756001, Odisha, India

7 School of Health Sciences, Universiti Sains Malaysia, Health Campus, Kubang Kerian 16150, Kelantan, Malaysia; edinur@usm.my

8 Faculty of Agro Based Industry, Universiti Malaysia Kelantan, Jeli 17600, Kelantan, Malaysia; zulhisyam.a@umk.edu.my

9 Haematology Department, School of Medical Sciences, Universiti Sains Malaysia, Health Campus, Kubang Kerian 16150, Kelantan, Malaysia

* Correspondence: drhaslina@usm.my (N.H.M.N.); raypumicro@gmail.com (R.R.R.)

+ Authors contributed equally.

Abstract: Bacterial cellulose (BC) is recognized as a multifaceted, versatile biomaterial with abundant applications. Groups of microorganisms such as bacteria are accountable for BC synthesis through static or agitated fermentation processes in the presence of competent media. In comparison to static cultivation, agitated cultivation provides the maximum yield of the BC. A pure cellulose BC can positively interact with hydrophilic or hydrophobic biopolymers while being used in the biomedical domain. From the last two decades, the reinforcement of biopolymer-based biocomposites and its applicability with BC have increased in the research field. The harmony of hydrophobic biopolymers can be reduced due to the high moisture content of BC in comparison to hydrophilic biopolymers. Mechanical properties are the important parameters not only in producing green composite but also in dealing with tissue engineering, medical implants, and biofilm. The wide requisition of BC in medical as well as industrial fields has warranted the scaling up of the production of BC with added economy. This review provides a detailed overview of the production and properties of $\mathrm{BC}$ and several parameters affecting the production of $\mathrm{BC}$ and its biocomposites, elucidating their antimicrobial and antibiofilm efficacy with an insight to highlight their therapeutic potential.

Keywords: natural polymer; biocomposite; nanocomposite; antimicrobial; antibiofilm

\section{Introduction}

Cellulose is a prime biopolymer due to its extensive productive importance. Chemically, it is linear homopolysaccharide, composed of $\beta$-D-glucopyranose units that remain linked by $\beta-1,4$ glycosidic bonds. Apart from being the most important structural component of the primary cell wall of green plants, cellulose is found to also be present in bacteria [1-3]. Cellulose is a group of carbohydrates that contains considerable amounts of hydroxyl groups that remain existent in the form of polymer chain [4] and has wide applications in pulp and paper and pharmaceutical industries and as a renewable fuel source. However, the plant 
cellulose is often associated with lignin, pectin, hemicellulose, and other biogenic products, which has made it difficult to obtain pure cellulose as substrate $[5,6]$.

Microbial cellulose is considered as a source of pure cellulose, which is usually synthesized by the bacteria. Because of its high purity and distinct physicochemical characteristics, it has widespread applications in various sectors such as food industries, bio-medical sectors, and for the formation of biobased polymers and nanocomposites [7-9].

For the past few decades, with the increasing awareness of environmental sustainability, there is an increasing surge for "going green", which has started searching for new biobased materials with high performance at affordable costs. Apart from having extensive utilization in the food and food packaging sectors, BC has several applications in "green" composite materials [5]. However, due to its high biocompatibility and biodegradability and other unique intrinsic properties, it is easier to functionalize BC to introduce antibacterial functional groups. This natural hydrogel is found to have promising applications in wound healing, as dry wounds need added moisture to ensure tissue regeneration. Although few review reports are available on bacterial cellulose [10-12], most of them focus on the biomedical applications of this versatile fiber. Hence, a review report is required to emphasize the antimicrobial and antibiofilm activities of the bacterial cellulose and its composites.

Utilization and optimization of different nutrient media have been prioritized in BC production to curtail downstream costs, and its antibacterial activity has been enhanced by organic, inorganic, and polymeric compounds and nanoparticles $[13,14]$.

The present overview discusses the bacterial production and unique features of bacterial cellulose with a special reference to its antimicrobial applications.

\section{Properties of Bacterial Cellulose}

Cellulose is the most liberal and viable sustainable polymer, and it is the one that is predominantly utilized. Though cellulose is considered a plant-based product, several fermentation techniques showed positive results in producing alternative sources of cellulose from bacterial genera. Though the $\mathrm{BC}$ and plant fiber have different physical and chemical properties, they have a similar structure with two discrete cellulosic subunits I and II [15]. The polymerization degree of cellulose varies from 2000-6000 in BC to 13,000-14,000 in plan cellulose. The 3D mesh-like structure of the cellulose prevents microbial attack. The $\beta-1 \rightarrow 4$ glycosidic linkage is responsible for the free surface hydroxyl group in the surface area of the cellulose. BC is $10-50 \mathrm{~nm}$ in diameter with $100-1000 \mathrm{~nm}$ in length $[16,17]$.

Hydrogen bonds are plentiful within cellulose (Figure 1) due to the presence of a large number of oxygen atoms and hydroxyl groups [18]. Parallel stacking is observed within cellulose due to the presence of van der Waals force that helps in the development of crystalline nanofibers followed by the development of microfibrillar structure [19]. The presence of the supercoil structure helps in promoting the hierarchical orders that help in providing a very high amount of mechanical strength to cellulose [20].

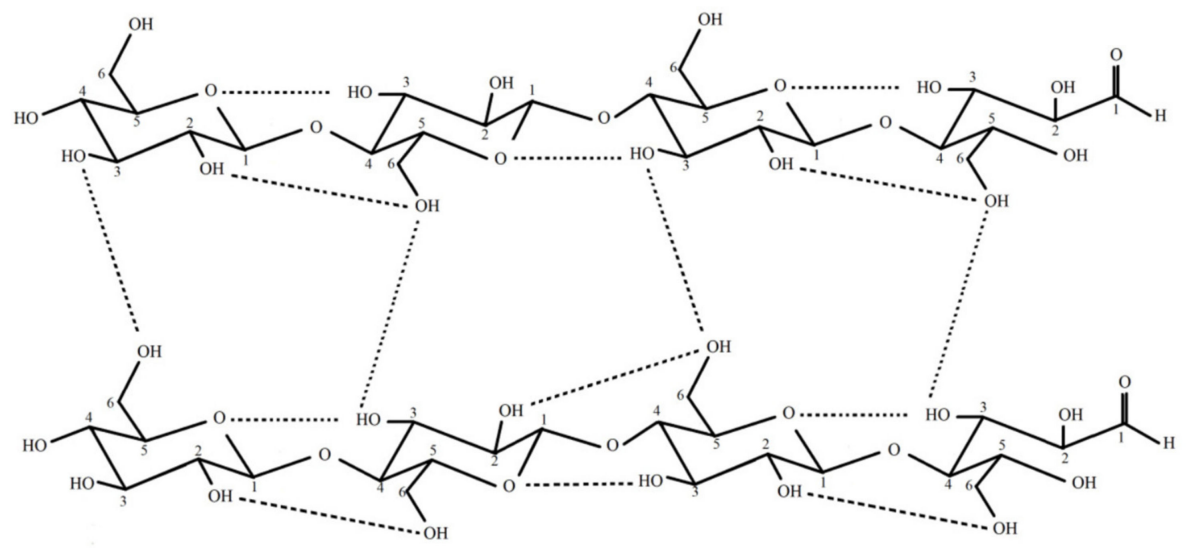

Figure 1. Inter and Intra hydrogen bonding between the bacterial cellulose (edited from FestucciBuselli et al., 2007)) adapted from [21]. 


\section{Bacterial Cellulose Producing Bacteria}

Very few bacterial species can synthesize cellulose, among which is Gram-negative bacterium Gluconacetobacter xylinus (conventionally known as Acetobacter xylinum) [22]. Researchers discovered the bacterium responsible for the production of cellulose as microfibrils on a large scale $[4,23]$. This group of Gram-negative, rod-shaped aerobic bacteria, due to the high yield of cellulose, is considered to be a model organism for the production of $\mathrm{BC}$ [24] for commercial fermentation.

Apart from this group, BC can be synthesized by other bacterial genera such as Agrobacterium spp., Acetobacter spp., Azotobacter, Rhizobium spp., Sarcina, Alcaligenes, and Pseudomonas [25]. Acetobacter, a common vinegar bacterium, is a non-photosynthetic advanced purple bacteria that can convert glucose, glycerol, sugar, or any other organic substances into pure cellulose [26,27]. In the growth medium, microfibrils are merged from each synthetic site to form large-ribboned cellulose, which is non-motile due to the formation of floating pellicles with the entangled associated cells. Apart from plant host cells, tumor-forming bacterium Agrobacterium tumefaciens also secretes cellulose fibrils which surround the cell in order to promote cell attachment and virulence [28]. Both Agrobacterium tumefaciens and Gluconacetobacter xylinus can be grown widely in a suitable medium, whereas mutants of both species are impaired in cellulose biosynthesis. The genus Komagataeibacter has also been found to be noteworthy for its cellulose producing ability [29].

The production of cellulose take place under the presence of various types of precursors, including hexanoates, hexoses, the three carbon compounds pyruvate, dihydroxyacetone, pyruvate, and glycerol, along with the presence of four-carbon compounds such as dicarboxylic acid, which is associated with citrate cycle [30]. The rate of synthesis of the $\mathrm{BC}$ remains unaffected by the inhibitors that are associated with protein synthesis at the resting stage of the bacterial cells [31]. It has been observed that bacteria similar to A. xylinum retain the cytoplasmic enzymes when incubated with UDP-[14C] glucose in the presence of bis-( $\left(3^{\prime}, 5^{\prime}\right)$ cyclic diguanylic acid (c-di-GMP) or GTP. A. xylinum is the model organism in which the entire phenomenon of the development of $\mathrm{BC}$ can be observed from glucose. The mechanisms of phosphorylation of glucose in the presence of glucokinase followed by the process of isomerization of glucose-6-phosphate to glucose-1-phosphate in the presence of the enzyme phosphoglucomutase act as important steps in the synthesis of BC (Figure 2).

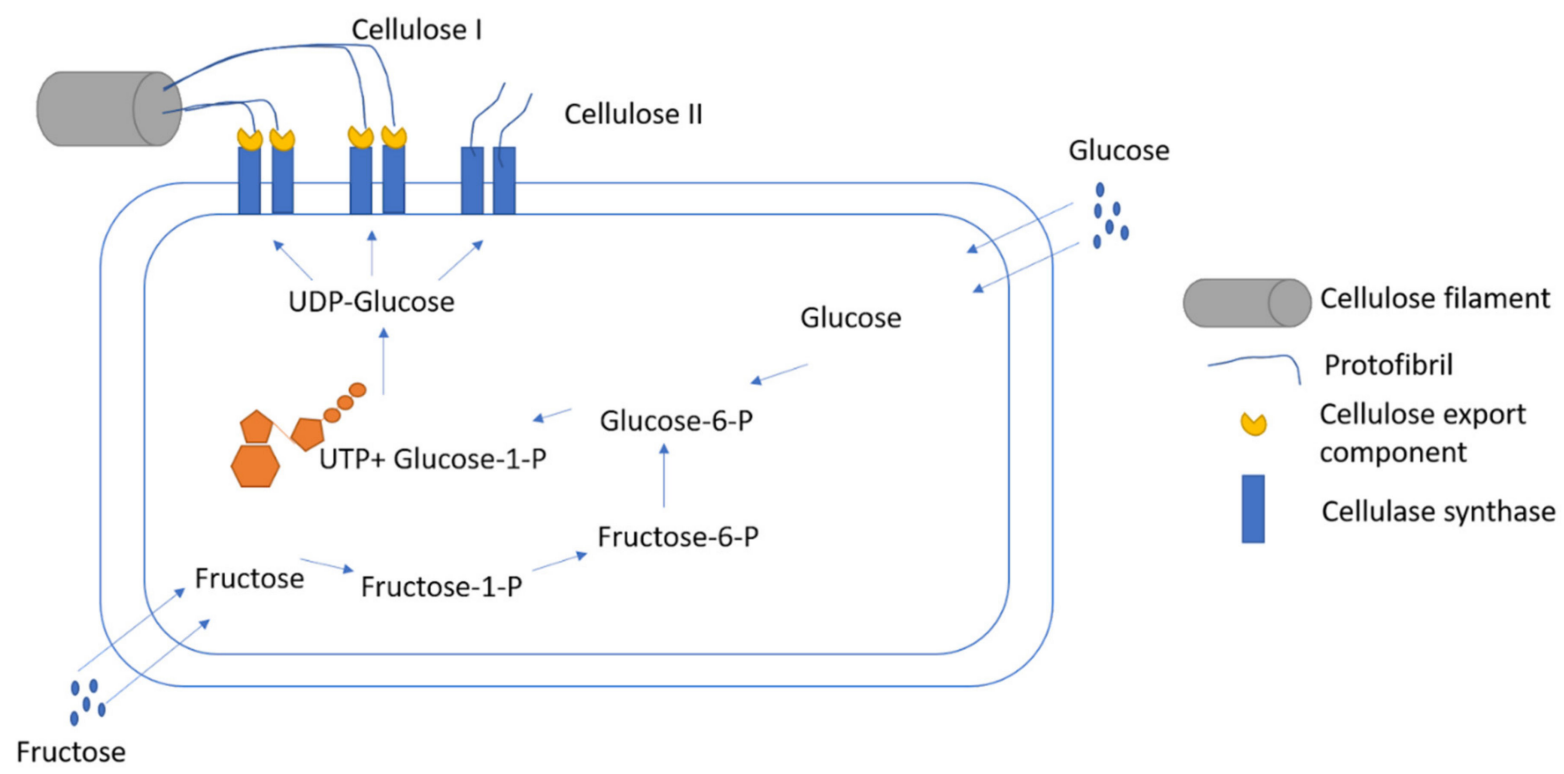

Figure 2. Biosynthesis of cellulose I and cellulose II from glucose and fructose in bacterial cell. 


\section{Cultivation of Bacteria for the Production of Bacterial Cellulose}

Fermentation for the production of BC is conducted in static and agitated or stirred mode, and with the change of mode, different forms of cellulose are produced. Under the static condition, three-dimensional interconnected reticular pellicles are formed, whereas sharp, irregular sphere-like cellulose particles (SCP) are produced in agitated or stirred conditions. Cellulose formation under static conditions is regulated by the supply of carbon and air into the medium. BC formation is increased with the increase in growth time and the $\mathrm{C}-\mathrm{H}$ bonding. When the pellicle growth slows down and all the bacteria are entrapped, the synthesis of $\mathrm{BC}$ reaches its threshold. Compared to continuous processes, semi continuous processes are put forward in all the industrial scale in order to achieve maximum BC productivity. For commercial production of BC with high yield, agitated fermentation has been used over static fermentation.

The production of $\mathrm{BC}$ can be achieved by both agitated and static fermentation. The process involved in the production of $\mathrm{BC}$ depends on the morphologies and the properties of $\mathrm{BC}$ to be produced [32]. The formation of gelatinous pellicles takes place in static culture at the air-liquid interface of the culture media, whereas in an agitated fermentation system, the irregular pellets are developed and remain totally suspended in the culture media. Since higher genetic stability is found among the bacterial species, cultured by static fermentation technique [4], the agitated fermentation can be more easily scaled up for the purpose of industrial production [19], although there may be a chance of the appearance of non-cellulosic bacterial mutant that can drastically decrease the productivity [12]. Varied microscopic morphology with 3D reticulate network has been observed with the $\mathrm{BC}$ obtained by static or agitation-based fermentation mechanisms [22]. The BC obtained from the agitation fermentation possesses a very low degree of polymerization and also exhibits a lower level of crystallinity in comparison to those obtained from the static fermentation techniques [33]. CP/MAS 13C NMR analysis reveals that the proportion of $I \alpha$ is lower but $I \beta$ is quite higher in agitation fermentation obtained $B C$ than that of $\mathrm{BC}$ yielded from static fermentation [34]. The mechanical properties vary in BC obtained from static to agitation fermentation, since Young's modulus of the BC obtained from static fermentation technique exhibits a higher value in comparison to those obtained from the agitation fermentation technique [35]. It has been observed that $\mathrm{BC}$ produced by the technique of static fermentation requires raw materials possessing fixed geometrics, high water holding capacity, and good wet tensile strength. The optimized culture media required for production of $\mathrm{BC}$ include $0.5 \mathrm{wt} \%$ peptone, $0.5 \mathrm{wt} \%$ yeast extract, $0.27 \mathrm{wt} \%$ $\mathrm{Na}_{2} \mathrm{HPO}_{4}, 2.0 \mathrm{wt} \%$ glucose, and $0.115 \mathrm{wt} \%$ citric acid [36]. The cost of production of $\mathrm{BC}$ is too high for it to be sustained for various industrial processes; thus, alternative strategies are being studied for the development of cost-effective mechanisms [37]. Various mechanisms involve promotion in the production of $\mathrm{BC}$, including the isolation of bacterial strains that are responsible for the production of $\mathrm{BC}$ and the detection of high-yielding strains with the use of genetic engineering and traditional mutagenic methods [38] and optimization of the various culture conditions [35]. Various types of carbon sources such as sucrose, fructose, molasses, arabitol, and mannitol, and nitrogen sources such as peptone, yeast extract, and corn steep liquor, are used for the purpose of producing BC [39]. Various types of agricultural residues can be also used for the production of BC [40].

The mechanism of fermentation is followed by the removal of impure raw pellets of $B C$ that comprise metabolic substances and nutrient residues along with $B C$. The mechanism of purification can be achieved by the treatment of $\mathrm{BC}$ with alkaline solution at a temperature of $1000{ }^{\circ} \mathrm{C}$ for $15-20 \mathrm{~min}$ to remove the bacterial cells. This is followed by the washing of the pellets with distilled water to recover the $B C$ pellets and recover the value of $\mathrm{pH}$ [17].

Interestingly, a cell-free enzyme system is also developed to produce $B C$, which might transform into a cell-free factory for $\mathrm{BC}$ production in the future. The cell-free enzyme system is developed from BC-producing strains and contains whole enzymes and cofactors required for BC synthesis. Quantitative analysis reveals that the system produces BC with a higher yield than the corresponding bacteria [41]. Further study demonstrates 
that the cell-free enzyme system produces $\mathrm{BC}$ via an anaerobic biosynthesis process, and the premature $\mathrm{BC}$ pellicles formed in the culture media move to the air-liquid interface and assemble into a sheet [42]. B-(1-4)-glucan chains become polymerized into the cell wall before being delivered into the culture medium. The mess structure of the $\mathrm{BC}$ gives it pores through which cellulose-synthesizing complex perceives place between plasma membrane and outer membrane of the cells. In this mechanism, the initial material, uridine diphosphate glucose (UDP glucose), is expanded into the cellulose chain, resulting in the development of basic fibril, which is assembled with the elementary fibrils in order to develop microfibrils and strips [43-45].

The fermentation medium is incubated for $1-14$ days in $\mathrm{pH} 4-7,28$ to $30^{\circ} \mathrm{C}$ with the inoculum, until the vessel gets filled by cellulose. The proper aeration and formation of $\mathrm{CO}_{2}$ control the metabolic activity in the production of BC. Compared to static cultivation, agitated cultivation is expensive due to the continuous agitation, which increases production yield [46]. In the stirred cultivation process, cellulose is produced in the form of solid balls. The increase in the shear rate may increase the bio productivity, although elevated share rate results in formation of turbulence force in the medium, leading to the change of cellulose-producing strains to the cellulose negative strains. Both the stirred tank bioreactor and air-lift bioreactor showed positive results with high productivity of the $\mathrm{BC}$ in highly viscous and dense fibrous suspensions. In the context of oxygen mixing, an air-lift bioreactor showed more efficiency over a stirred tank reactor, as from the bottom, the vessel oxygen is transferred continuously to the culture medium in order to provide an aerobic atmosphere. An airlift bioreactor showed efficiency in controlling energy and shear stress to control the production of cellulose-negative mutants.

\section{Parameters Controlling BC Production}

Several parameters such as dissolved oxygen, $\mathrm{pH}$, and temperature, independent of static or agitated cultivation, need to be optimized to improve BC yield (Table 1) [47]. Crystalline polymorph, crystallinity index $(\mathrm{CI})$, cellulose $\mathrm{I} \alpha$, and size are the factors that determine microstructure, and these are dependent on culture conditions [48].

\subsection{Temperature}

One of the most important parameters is the temperature, which can regulate the adaptation pattern of an organism for its survival by influencing the normal homeostatic physiology. A temperature range of 25 to $30^{\circ} \mathrm{C}$ was found to be best for the production of $\mathrm{BC}$, as a Komagataeibacter sp. Was cultivated at $30^{\circ} \mathrm{C}$ for 7 days under static conditions [29], whereas $28^{\circ} \mathrm{C}$ is the optimum temperature for the $\mathrm{BC}$ production by Acetobacter xylinum [27,49]. A slightly higher temperature of $33.5^{\circ} \mathrm{C}$ was required by Acetobacter senegalensis MA1 [50]. For BC production by Gluconacetobacter, sp. RV28, Pseudomonas sp. RV14, and Enterobacter sp. RV11 preferred a range of temperature that was found to be $28-30{ }^{\circ} \mathrm{C}$ [51], as high temperatures cause denaturation of the culture environment, whereas low temperatures slow down cellular metabolism by supplying low energy for cell development.

\section{2. $p H$}

$\mathrm{pH}$ is another important factor in controlling oxidative fermentation of $\mathrm{BC}$ production. Acidic or near-neutral $\mathrm{pH}$ is suitable for $\mathrm{BC}$ production. During the fermentation process of $\mathrm{BC}$, production of secondary metabolites such as acetic acid, gluconic acid, and lactic acid independently shifts the $\mathrm{pH}$ of fermentation culture media [47]. Thus, $\mathrm{pH} 4-6$ is considered the ideal $\mathrm{pH}$ for the fermentation culture medium of $\mathrm{BC}$. Experimental observations indicate that $\mathrm{pH}$ of 5.50 for Acetobacter xylinum [52], 4.5 to 7.5 for another strain of Acetobacter xylinum [27], and 6.0 for Komagataeibacter spp. [29] are required. 


\subsection{Culture Media}

Carbon, in the form of fructose, glycerol, maltose, starch, and xylose, and nitrogen, in the form of casein hydrolysate and peptone, are the main components of the growth medium required for $\mathrm{BC}$ fermentation. Alteration of growth media has direct or indirect effects on microbial growth patterns. A $5 \mathrm{~g} / \mathrm{L}$ yield of $\mathrm{BC}$ and a $4.8 \mathrm{~g} / \mathrm{L}$ yield of $\mathrm{BC}$ from A. xylinum were reported in presence of casein hydrolysate and peptone, respectively [53]. Vitamins are important in regulating cellular metabolism and growth. Apart from pantothenate and riboflavin, vitamins such as pyridoxine, nicotinic acid, biotin, and p-aminobenzoic acid are required for cellular synthesis [54]. It was observed that in the presence of lignosulphonate, a low formation rate of gluconic acid increases the productivity of BC [55]. A medium with $0.38 \%$ agar, $2.85 \%$ corn steep liquor, $4.99 \%$ fructose, and $28.33 \%$ dissolved $\mathrm{O} 2$ is suitable for the formation of $14.0 \mathrm{~g} / \mathrm{L}$ of BC [56]. Optimized cultivation of Gluconacetobacter sp. RKY5 in agitated and static culture produces $5.63 \mathrm{~g} / \mathrm{L}$ and $4.59 \mathrm{~g} / \mathrm{L}$ of $\mathrm{BC}$, respectively [57]. Using dual carbon sources such as fructose and sucrose, around $8.79 \mathrm{~g} / \mathrm{L}$ yield of $\mathrm{BC}$ was reported. Cheaper carbon sources such as molasses, muskmelon, orange juice, and watermelon can be used for $\mathrm{BC}$ production, and among them, muskmelon is recognized for the highest yield of BC $0.08 \mathrm{~g} / \mathrm{L}$. Even so, BC-producing cells have the unique feature of using the nutritional medium for the inexpensive production process.

Table 1. Yield of BC with the variation of bacterial strains, culture medium, and cultivation methods.

\begin{tabular}{|c|c|c|c|c|}
\hline Medium & Bacterial Strain & Incubation Days & Yield of BC $\mathrm{g} / \mathrm{L}$ & Reference \\
\hline Glycerol & Gluconacetobacter sp. RKY5 & 6 & $\begin{array}{l}4.59 \mathrm{a} \\
5.63 \mathrm{~b}\end{array}$ & [57] \\
\hline \multirow{5}{*}{ Glucose yeast extract broth } & Acetobacter xylinum K086 & \multirow{5}{*}{7 days } & $0.14-0.39 \mathrm{a}$ & \multirow{5}{*}{ [58] } \\
\hline & Acetobacter xylinum K975 & & $1.11-1.55 \mathrm{a}$ & \\
\hline & Acetobacter xylinum K428 & & $0.09-0.22 \mathrm{a}$ & \\
\hline & Acetobacter xylinum K1011 & & $0.57-1.46$ a & \\
\hline & Acetobacter xylinum KX & & $1.14-1.84 \mathrm{a}$ & \\
\hline Glycerol & Acetobacter sp. V6 & 7 days & $4.98 \mathrm{~b}$ & [59] \\
\hline Molasse & \multirow{2}{*}{$\begin{array}{c}\text { Komagataeibacter } \\
\text { sucrofernentans H110 } \\
\text { Komagataeibacter hansenii C110 }\end{array}$} & \multirow{2}{*}{14 days } & $8.2 \pm 0.2 \mathrm{a}, 8.1 \pm 0.2 \mathrm{a}$ & \multirow{2}{*}{ [60] } \\
\hline Stillage & & & $9.5 \pm 0.1 \mathrm{a}, 9.2 \pm 0.1 \mathrm{a}$ & \\
\hline Citrus waste solution & \multirow{3}{*}{$\begin{array}{l}\text { Gluconacetobacter intermedius } \\
\text { CIs } 26\end{array}$} & \multirow{3}{*}{8 days } & $7.2 \mathrm{a}$ & \multirow{3}{*}{ [61] } \\
\hline HS media & & & $2.1 \mathrm{a}$ & \\
\hline Citrus waste modified HS & & & $5.7 \mathrm{a}$ & \\
\hline Glucose & \multirow{3}{*}{ Gluconacetobacter hansenii } & 2 & $1.33 \mathrm{~b}$ & [62] \\
\hline Glucose (modified HS Media) & & 14 & \multirow{2}{*}{$14.72 \mathrm{a}$} & \multirow{2}{*}{ [63] } \\
\hline Mannitol (modified HS media) & & 20 & & \\
\hline Pineapple peel juice & Gluconacetobacterswingsii & 13 & $2.8 \mathrm{a}$ & [64] \\
\hline
\end{tabular}

a: static cultivation, $\mathrm{b}$ : agitated cultivation.

\subsection{Agitation Rate}

Production of $\mathrm{BC}$ is affected by another important parameter, i.e., agitation rate. At a lower agitation rate of $100 \mathrm{rpm}$, a uniform solid ball of 0.5 to $1 \mathrm{~cm}$ diameter is formed. With an increase of agitation rate around 150 to $250 \mathrm{rpm}$, BC size decreases, and at $300 \mathrm{rpm}$, irregularly shaped clumps are produced. Net $3,10,11.46,7.73$, and $3.91 \mathrm{~g} / \mathrm{L}$ yields of $\mathrm{BC}$ were obtained at 100,150,250, and $300 \mathrm{rpm}$, respectively, in the case of synthesis of cellulose from G. xylinus DSM46602. According to this observation, the moderate rpm is suitable for the optimal production of BC. The generation of shear stress during agitation provides stability to the mutant of cellulose-producing strains in order to enhance the net BC productivity. An increase in the impeller speed from 80 to $500 \mathrm{rpm}$ may decrease the cellulose-negative strains to almost zero. Agitation rate has an impact on the size of the $\mathrm{BC}$. 
It may decrease the size of $B C$ from $8 \mathrm{~mm}$ to $<1 \mathrm{~mm}$ [65]. The agitation rate needs to be optimized for the production of $\mathrm{BC}$ on a large scale as it varies for different microbes along with the culture medium.

\subsection{Oxygen Level}

Oxygen plays an important role in controlling aeration within the media. An adequate supply of oxygen is needed as all the microbes in the culture medium are aerobic in nature. Within the media, a low level of dissolved oxygen obstructs bacterial growth, leading to the retardation of $\mathrm{BC}$ production. $\mathrm{O}_{2}$ is essential for cellular metabolism and $\mathrm{BC}$ production. A restricted $\mathrm{O}_{2}$ supply not only collapses the $\mathrm{BC}$ production but also reduces $\mathrm{BC}$ quality. $\mathrm{O}_{2}$ transfer rate has an inverse relationship with the viscosity of the broth. An increase in viscosity decreases the $\mathrm{O}_{2}$ transfer rate as well as the $\mathrm{BC}$ productivity. Ten percent saturation of dissolved oxygen provides the highest yield of $\mathrm{BC}$ in the fedbatch cultivation [66]. Therefore, to obtain the highest yield of BC, a two-stage cultivation system has been developed by Liu et al., wherein in the first-stage dissolved $\mathrm{O}_{2}$ within the culture media is increased before reaching the log phase of the growth curve followed by maintaining the hypoxic condition at the secondary phase of the growth curve in the second phase for BC production [67].

\subsection{Growth Curve}

Analogously to the other bacterial strains, BC-producing strains have identical growth curve patterns with lag, log, stationary, and death phases. Komagataeibacter mendellinensis has a lag phase of $25 \mathrm{~h}$ when it is cultivated in growth media with carbon sources glucose, fructose, and sucrose in $2 \% w / v$ [68]. A five percent fructose in the culture medium is longer than the lag phase by around $10-15 \mathrm{~h}$ in the case of G. liquefaciens, leading to the long-time consumption in $\mathrm{BC}$ synthesis.

\subsection{Yield of $B C$}

Different bacterial strains favor different nutritional media independently of the cultivation technique. Cheap media such as citrus waste solution, pineapple peel, or molasses also assist in the production of $\mathrm{BC}$. The 2 to 14 days range is optimal for regulating cultivation of $\mathrm{BC}$ in order to obtain the highest yield. Overall increase in incubation days may increase the yield of $\mathrm{BC}$. Among all other sources, glucose is the main nutrient source of carbon, which is remarkably consumed by bacterial cells to attain the metabolic demands and high energy yield.

\section{Bacterial Cellulose Biocomposites and Their Characterization}

Bacterial cellulose has eccentric mechanical, morphological, and structural properties (Table 2). Due to these characteristics, $\mathrm{BC}$ has applications in diverse sectors including wound dressing, paper restoration, and blood vessel regeneration. In spite of having special characteristics, $\mathrm{BC}$ has restricted applications due to a lack of antibacterial properties, optical transparency, and stress-bearing capability. In order to overcome these limitations, $\mathrm{BC}$-based composites containing matrix and reinforcement material were introduced. The porous arrangement of fibers in addition to reinforcement materials make the matrix a biocomposite that has biological and physicochemical properties. $\mathrm{BC}$ composites are synthesized using an in situ method, where reinforcement materials are added into it during synthesis, and an ex situ method, where BCs are infused with reinforcement materials. 
Table 2. Characterization of BC and its composites.

\begin{tabular}{|c|c|c|c|}
\hline \multirow{2}{*}{ Characterization } & \multicolumn{2}{|r|}{ Properties } & \multirow{2}{*}{ References } \\
\hline & Absorption Peak & Functional Groups & \\
\hline \multirow{6}{*}{ FTIR } & $\sim 1160 ; \sim 1361 ; \sim 2895 ; \sim 3338$ & $\begin{array}{c}\mathrm{C}-\mathrm{O}-\mathrm{C} \text { antisymmetricbridge stretching of } \\
\text { 1,4- } \beta \text {-d-glucoside; } \mathrm{C}-\mathrm{H} \text { bending; } \mathrm{C}-\mathrm{H} \text { stretching of } \mathrm{CH} 2 \\
\text { and } \mathrm{CH} 3 ;-\mathrm{OH} \text { stretching }\end{array}$ & [69] \\
\hline & 1314; 1426 & $\begin{array}{c}\mathrm{CH} 2 \\
\text { groups out-of-plane bending; } \mathrm{O}-\mathrm{H} \text { in-plane bending }\end{array}$ & [70] \\
\hline & $\sim 1108$ & $\mathrm{C}-\mathrm{C}$ bonds of the monomer units of polysaccharide & [71] \\
\hline & $\sim 1335$ & $\mathrm{C}-\mathrm{H}$ deformation/-OH in-plane bending & [64] \\
\hline & $\sim 900$ & $\begin{array}{l}\text { Antisymmetric out-of-phase ring stretching for } \\
\qquad \text {-glucosidic linkages }\end{array}$ & [72] \\
\hline & $\sim 1054$ & Bending of the $\mathrm{C}-\mathrm{O}-\mathrm{H}$ bond of carbohydrate & [73] \\
\hline \multirow{3}{*}{$\mathrm{XRD}$} & \multicolumn{2}{|c|}{$\begin{array}{c}14.5^{\circ}, 16.4^{\circ} \text {, and } 22.5^{\circ} \text { diffraction peak corresponds to crystallographic planes of } \\
101 \text { (amorphous) and } 200 \text { (crystalline) }\end{array}$} & [74] \\
\hline & \multicolumn{2}{|c|}{$\begin{array}{l}\text { Due to the presence of preferential parallel orientation of the cellulose fibrils, } \\
112 \text { crystallographic planes are missed in BC diffraction pattern }\end{array}$} & [75] \\
\hline & \multicolumn{2}{|c|}{ intra and intermolecular H-bonding influences Crystallization } & [76] \\
\hline \multirow{2}{*}{$\begin{array}{l}\text { Tensile strength (TS) and Youngs' } \\
\text { modulus (YM) }\end{array}$} & \multicolumn{2}{|c|}{$0.26 \pm 0.02 \mathrm{MPa}$ TS and $0.005 \pm 0.0003 \mathrm{MPa} \mathrm{YM}$ for Wet BC } & \multirow{2}{*}{ [77] } \\
\hline & \multicolumn{2}{|c|}{$11.94 \pm 1.15 \mathrm{MPa}$ TS and $6.65 \pm 0.16 \mathrm{MPa}$ YM for lyophilized BC } & \\
\hline $\begin{array}{l}\text { Scannining Electron Microscopy } \\
\text { (SEM) }\end{array}$ & \multicolumn{2}{|c|}{ Helps in providing the structural morphology of the $B C$} & [78] \\
\hline $\begin{array}{l}\text { Differential scanning calorimetry } \\
\text { (DSC) }\end{array}$ & \multicolumn{2}{|c|}{ Helps in the determination of the stability of the BC } & [78] \\
\hline $\begin{array}{l}\text { Viscosity measurements of the } \\
\text { film-forming solution (FFS) }\end{array}$ & \multicolumn{2}{|c|}{ Helps in the purpose of analyzying the viscosity of the $B C$} & [78] \\
\hline Moisture content (MC) & \multirow{2}{*}{\multicolumn{2}{|c|}{ Helps in the estimation of the water resistance capasity of the film }} & [78] \\
\hline Water vapor permeability (WVP) & & & [78] \\
\hline
\end{tabular}

\section{Antimicrobial Activities of BC Composites}

\subsection{Deposition of BC on Electrospun PLA}

In Situ deposition of BC on electrospun PLA was illustrated by Xiang and Acevedo in 2017. In $8 \mathrm{wt} \%$ in chloroform/acetone (3:1 v/v) solution, PLA was dissolved followed by the acquisition of PLA fiber mats with $100 \mathrm{~mm}$ cross-sectional diameter through electrospinning. BC/PLA spectral bands within the nanocomposites showed absorption peaks at $1746 \mathrm{~cm}^{-1}$ and $3200-3500 \mathrm{~cm}^{-1}$, and they showed O-H stretching bands due to the modification of electrospun PLA with BC nanofibers [79]. Incorporation of PLA in BC does not influence the crystalline morphology of $\mathrm{BC}$, although a higher $\mathrm{CI}$ of $83.3 \% \pm 4.3 \%$ was derived from the XRD analysis of BC/PLA composites [79]. Electrospun nanofibers containing $\mathrm{BC}$ functionalized with antimicrobial agents have shown enhanced antibacterial performance compared to traditional dressings [80] and are nowadays regarded as a promising wound dressing material due to their antibacterial, antiviral, and antiinflammatory activities, as well as their ability to maintain an appropriate environment for wound healing [81].

\subsection{BC-Reinforced Fabrics with Natural Fibers}

In order to produce hierarchical fiber-reinforced nanocomposites, $\mathrm{BC}$ is cultivated on hemp and sisal fiber via agitation [82]. In order to prepare green nanocomposite, $B C$ is bonded with flax fabric (FF) and little PLA was used to wet the FF attached BC through the casting method. BC-modified hemp fiber is arbitrarily organized, having a diameter of 50-100 nm, and it encircles the fiber surface [83]. The pore size between the two fabric threads is reduced, resulting in the uniform distribution of PLA-modified BC-attached FF composites 
(PLA-BC-FF). Antibacterial activity is manifested by the PLA-BC-FF biocomposites, which was revealed by forming zone of inhibition against Gram-negative E.coli.

Antibacterial activity of the BC composites' surface functionalized with benzalkonium chloride-based product was found against Escherichia coli and Staphylococcus aureus [84].

\subsection{BC-Reinforced Chitosan (BC-Ch) Composite}

The specific two methods i.e., impregnation by immersion and impregnation in mass, are mainly used for preparation of BC-Ch composite. The whole BC is immersed directly into the chitosan molecules in the form of paper or matrix, and then it proceeds to dry in the case of BC-ChI. For preparing BC-ChM BC is mixed to chitosan mechanically and incubated for a fixed time [85]. Besides these two methods, another method is used for $\mathrm{BC}-\mathrm{Ch}$ preparation wherein chitosan is placed inside the bioreactor, and in each step, $0.25 \%$ of chitosan concentration is incremented from 0 to $0.75 \%$ [86]. Chitosan is uniformly distributed throughout the $\mathrm{BC}-\mathrm{Ch}$ nanocomposite, and immersing $\mathrm{BC}$ within the chitosan molecules enhances the binding and interaction of the surface fibers. $\mathrm{BC}-\mathrm{ChI}$ has more condensed morphology than BC-ChM [87]. BC-Ch nanocomposite fiber size is asymmetric due to the impediment of the assembly of BC nanofibers. Impregnation of chitosan into natural $\mathrm{BC}$ showed a reduction in the bacterial growth upon the fibers. The antibacterial assay provides the result of the consequential diminution of Gram-positive Staphylococcus aureus and Gram-negative Pseudomonas aeruginosa. It was also observed that BC-ChM is more effective compared to $\mathrm{BC}-\mathrm{ChI}$ in inhibiting microbial growth due to its firm surface and bacteriostatic activity of the chitosan [86]. The BC/Ch composite showed antibacterial activity against $S$. aureus, E. coli, and P. aeruginosa [88]. BC-Ch nanocomposites are also found to have antimicrobial effect against the yeast Candida albicans [89].

Chitosan/bacterial cellulose composite films containing diamond nanoparticles (NDs) were found to be effective against Staphylococcus aureus ATCC 25,922 and Escherichia coli ATCC) 25,923 [90]. The antibacterial activity of the starch/chitosan-based biocomposite films with BC was assayed found against Staphylococcus aureus, Bacillus subtilis, Escherichia coli, and Pseudomonas aeruginosa [91].

\subsection{Montmorillonite (MMT)-Reinforced BC Composite}

Suspension culture and in situ preparation are the two main methods used to prepare $\mathrm{BC}$ biocomposites reinforced with MMT (BCMMT). Different concentrations of MMT $(0.5,1.0,2.0 \%)$ are mixed with $\mathrm{BC}$ by a mechanical shaker for $72 \mathrm{~h}$ at $150 \mathrm{rpm}$ to obtain BCMMT0.5, BCMMT1, and BCMMT2. Similar concentration of MMT is added to the water within the ultrasonicator for $1 \mathrm{~h}$ to make MMT/water dispersion followed by addition of it into the $\mathrm{BC}$ growing medium for 13 days at $28^{\circ} \mathrm{C}$ in order to produce in situ BCMMT composite [92]. In Situ BCMMT biocomposite has a compact network with MMT nanolayers and BC nanofibers [63]. The antibacterial activities of the composites were then assessed against Escherichia coli and Staphylococcus aureus through the disc diffusion assay. Such antibacterial activities are utilized in the development of BC sheets as wound dressings and regeneration materials for therapeutic applications without any side effects [93].

\section{BC-CU NPs Nanocomposites}

The combination of copper nanostructure along with BC showed an effective antimicrobial activity. It has been observed that the nanocomposite showed antibacterial potential against nosocomial organisms such as Klebsiella pneumonia and Staphylococcus aureus. The chemical structure and morphology of the nanocomposite provided a great efficacy to act as potent antibacterial agent. The BC composite showed an effective antibacterial potential along with the nanocomposite [94].

\section{BC-Graphene-CuO Nanocomposites}

The antibacterial potential of the BC-graphene CUO showed marked antibacterial potential. It has been observed the $\mathrm{CuO}$ nanosheets have a length of 50-200 $\mathrm{nm}$ and a width 
of 20-50 nm. The nanocomposites exhibited its activity against Gram-positive bacteria in comparison to that of the Gram-negative bacteria. It has been further observed that the $\mathrm{BC}$-grapheneoxide- $\mathrm{CuO}$ nanocomposites have greater efficacy in comparison to that of the $\mathrm{BC}-\mathrm{CuO}$ nanocomposites. It further exhibited biocompatibility with that of the mice fibroblast cells and can be used as an excellent antibacterial material [95].

\section{BC-ZnO Nanocomposites}

BC-ZnO nanocomposites showed excellent antibacterial potential against Grampositive and Gram-negative bacterial cells and had excellent biomaterial properties. They also exhibited photocatalytic activity and were able to degrade $91 \%$ methyl orange dye under the influence of UV irradiation for a period of $2 \mathrm{~h} \mathrm{[96].}$

\section{BC-Methylglyoxal Nanocomposites}

BC cellulose produced by Acetobacter xylinum exhibited wound-healing properties in association with methylglyoxal, resulting in the formation of BC-Methylglyoxal nanocomposites. They exhibited stability at a higher range of temperature and exhibited a considerable amount of mechanical strength. The nanocomposite showed its efficacy against Staphylococcus aureus, Micrococcus luteus, Pseudomonas aeruginosa, and Escherichia coli, thereby making it an alternative would-healing biocompatible material [97].

\section{Antimicrobial Activities of Bacterial Cellulose Augmented with Other Compounds}

Bacterial cellulose supplemented with povidone-iodine, polyhexamethylene biguanide, and octenidine-like antimicrobial agents showed around 1.5-fold increased antimicrobial activities against both Gram-positive and Gram-negative bacteria. The overall compressive strength of the combined material was augmented, increasing the antimicrobial activity by around $65 \%$ against $S$. aureus [98]. A cationic surfactant benzalkonium chloride exhibited antimicrobial activities against Gram-positive bacteria and can also be used for wound dressing. After being submerged for $24 \mathrm{~h}$, EDA-DLA-Tyr becomes attached to bacterial cellulose, and the composite shows antibacterial activity against Staphylococcus aureus and Staphylococcus epidermidis. However, the activity of the bacterial cellulose is enhanced when the antibiotic amoxicillin is incorporated into it. In order to make the formation of cross-linkage between BC and amoxicillin, BC is treated with 3-aminopropyltrieoxysilane to create the bond with aminoalkysilane groups through $\mathrm{Si}-\mathrm{O}-\mathrm{C}$ bonding. After treatment with the drug carbodiimide-crosslinked EDC/NHS (1-ethyl-3-(3-dimethyl aminopropyl)carbodiimide hydrochloride), the carboxylic group is added to amoxicillin. The modified amoxicillin with the activated ester group form covalent bonds to the NH2 of $\mathrm{BC}$, resulting in the formation of a $\mathrm{BC}$ composite that is able to reduce $95 \%$ of the C. albicans, E. coli, and S. aureus cell viability [99]. Eighty-two percent of the all loaded drugs are released within $48 \mathrm{~h}$ application of the tetracycline-loaded BC, and it is able to reduce $99.9 \%$ of the viability of the S. aureus and B. subtilis [100].

\section{Antibiofilm Activities of BC Composites}

\subsection{Antibiofilm Effect of Bacterial Cellulose-Tannic Acid Composite}

Biofilm refers to a consortium of microorganisms that remain embedded within the self-produced extracellular polymeric substances (EPS) upon the biotic or abiotic inert surface [101]. EPS includes exopolysaccharides, proteins, and extracellular DNA, which manifest the strong barrier against any external stresses such as antibiotics or host immune responses [102]. Biofilm is responsible for $80 \%$ of the microbial infections associated with bacteria, fungi, protozoa, viruses, or bacteriophages in the human body [103]. Complete lavage of infections becomes difficult when biofilm is formed upon the wound bed, even though a small portion of bacterial cells remains attached to the wound bed after treatment with the strong antibiotics, resulting in regeneration of biofilm with high infections [104]. Apart from the growth upon abiotic surfaces of medical devices such cardiac pacemakers, 
contact lenses, urinary and intravascular catheters, and tissue fillings, it is responsible for about $60-70 \%$ of the nosocomial infections. To combat the biofilm-mediated infections, the main strategy is to inhibit bacterial adhesion and its growth, which may not be achieved by using only antibiotics, since biofilm bacteria are impenetrable and difficult to remove, leading to the emergence of antibiotic resistance. The development of antifouling or antimicrobial surfaces can be an alternative strategy to arrest microbial adhesion. Another therapeutic strategy could be using microbial peptides against biofilm formation. Photodynamic therapy can be one of the potential antibiofilm methods with several side effects such as residual skin photosensitivity and pain in the treated area. Quorum quenching and inhibition of intra- or inter-bacterial signaling are the main strategies to inhibit biofilm formation, which can be accomplished by tannic acid, and hence are used against two chronic infectious pathogens $S$. aureus and P. aeruginosa $[105,106]$.

Since TA shows antibacterial activity against a wide range of invasive bacteria causing wound infections, and since 3D composites made of TA-graphene show antibacterial activity [107], TA is effectively used to make composites with BC. BC, as a natural biopolymer with high mechanical strength, water uptake, and biocompatibility, has 3D-nanofiber networks and chemical reactive groups, which facilitate the penetration of molecules into its inner space. Incorporation of TA into BC creates a shortage of microbial activity of the BC. Magnesium acts as the crosslinker between the TA and the BC in order to form BC-TA-Mg biocomposite. The novel BC-TA-Mg composite exhibits antimicrobial and antibiofilm activity and shows antimicrobial activity against $S$. aureus, P. aeruginosa, and E. coli with the zone of inhibition of $17.30 \pm 0.53 \mathrm{~mm}, 15.07 \pm 1.05 \mathrm{~mm}$, and $14.39 \pm 0.80 \mathrm{~mm}$ diameter, respectively. Diameter of inhibition also shows that BC-TA-Mg is more effective on Gramnegative bacteria compared to Gram-positive. Since BC does not have any negative impact on biofilm formation, preparation of BC-TA-Mg biocomposite is required to inhibit biofilm formation. It was found that $24 \mathrm{~h}$ incubation with composite could effectively reduce the viable cell count of $S$. aureus and P. aeruginosa. Although $\mathrm{Mg}^{2+}$ affects the inhibitory effect of the composite by stimulating cell-cell adhesion and aggregation by interacting with cell-wall teichoic acid, it does not hamper the anti-biofilm activity against $S$. aureus and P. aeruginosa.

\subsection{Antibiofilm Effect of Silver-BC Composite}

Another method of enhancing the antibacterial activity is the incorporation of silver particles to produce BC-silver particle composites. Silver shows a robust cytotoxicity against a broad spectrum of micro-organisms. Due to the presence of an oligodynamic effect, silver ions exhibit bacteriostatic as well as bactericidal effects. Silver nanoparticles containing BC membranes can decompose silver nitrate hydrolytically with the help of triethanolamine complex. TEA is used as stabilizer as well as a reducing agent, leading to the dispersion of spherical particles [108]. BC-Ag-TEA composites show strong antimicrobial activity against both Gram-positive and Gram-negative bacteria. A $1 \mathrm{~mol} / \mathrm{L}$ concentration of BC-Ag-TEA composite shows activity against Staphylococcus aureus and Pseudomonas aeruginosa. A $2 \mathrm{~cm}$ zone of inhibition in agar diffusion method allowed the diffusion of silver NP in culture medium from BC-Ag-TEA composite [109]. Silver ions interact with biological macromolecules via the thiol (-SH) group of proteins and replace the $\mathrm{H}+$ of the sulfhydryl or thiol groups by Ag+, resulting in the inactivation of proteins and the decrease of cellular permeability, leading to cell death. Upon the bacterial cell surface, a stable -S-Ag group is produced via the reaction between the monovalent silver and the sulfhydryl group. Silver ions are incapable of penetrating the cell membranes and do not react with interior -S-H groups, resulting in persistence of silver in nontoxic form [110].

\subsection{Antibiofilm Activity of Chitosan-BC Composite}

Chitosan is considered an antibacterial agent as it is able to bind to the negatively charged bacterial cell wall, leading to the alteration of cell permeability and cell disruption (Figure 3). It also becomes attached to the DNA of the cells, resulting in the inhibition 
of DNA replication and cell apoptosis [111]. Furthermore, chitosan acts as a chelating agent, which binds to the metal elements of the cell and exhibits toxin production, resulting in inhibition of microbial growth [112]. The polycationic structure of the chitosan is responsible for the antibacterial activity $[113,114]$. The $\mathrm{pH}$ below the $\mathrm{pKa}$ of the chitosanbased $\mathrm{BC}$ composite helps the electrostatic interactions between the composite and the anionic components of the microorganisms. This is the principle of the antibacterial activity of the chitosan-based $\mathrm{BC}$ composite [115]. A higher $\mathrm{pH}$ condition is responsible for the protonation of chitosan, resulting in an increase in the antibacterial properties. Apart from protonation, the linkage between the amino groups and C-2 on chitosan backbones is required for electrostatic interactions. The incorporation of amino groups enhances antimicrobial activity of the composite. Asparagine N-conjugated chitosan oligosaccharide has two positively charged sites, which allow stable interaction with carboxyl-negative charges on the bacterial cell wall [116]. Chitosan, along with nanoparticles, alter cell permeability by interacting with the cell surface and interrupting the entry of the essential solute into the cells.

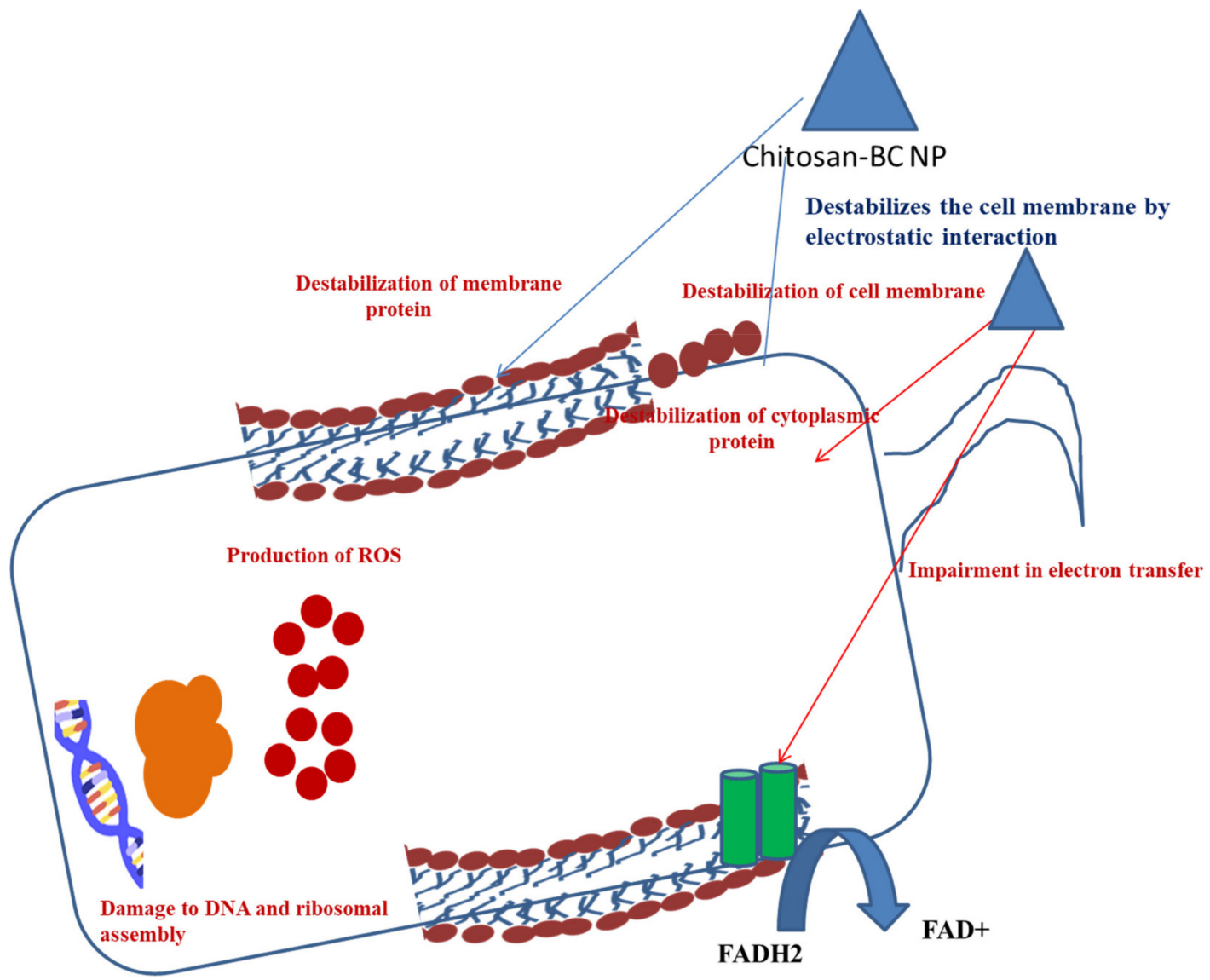

Figure 3. Antimicrobial effects of chitosan BC composite.

Incorporation of nanomaterial into the chitosan reveals the anti-biofilm properties against both the Gram-positive Listeria monocytogenes and S. aureus and Gram-negative $P$. aeruginosa and S. typhimurium. Chitosan-streptomycin gold nanoparticles are able to disrupt the EPS of the biofilms in order to inhibit biofilm formation. Streptomycin conjugated chitosan-gold nanomaterial can penetrate through the biofilm matrix and develop contact with the bacterial surface, leading to the enhancement of the bactericidal effect. Methylene blue (MB)-mediated antimicrobial photodynamic inactivation (APDI) is enhanced by the chitosan nanomaterial and stimulates disruption of $S$. aureus and P. aeruginosa biofilms [117]. 
Apart from these three $\mathrm{BC}$ composites, several active compounds are amalgamated with $B C$ to enhance its activity against microbes. Polyhexanide, octenidine dihydrochloride, benzalkonium chloride, tetracycline, amoxicillin, povidone iodine, lysozyme, dehydrogenative polymers, zinc oxide, and gold nanoparticles are the few compounds that are reported to be amalgamated with the BC. All of these composites possess antibacterial and antibiofilm activities.

\section{Dye- and Heavy-Metal-Removal Activities of BC Composites}

Heavy metals such as $\mathrm{Pb}^{2+}, \mathrm{Cu}^{2+}$, and $\mathrm{Cr}^{6+}$, and anionic organic dyes such as Congo red (CR) can be removed by batch adsorption by bc-attapulgite magnetic composites [118]. In another experiment, $\mathrm{Pb}^{2+}$ and $\mathrm{Cu}^{2+}$ could be successfully adsorbed on composite hydrogel of BC prior to removal [119]. Figure 4 represents various applications of BC.

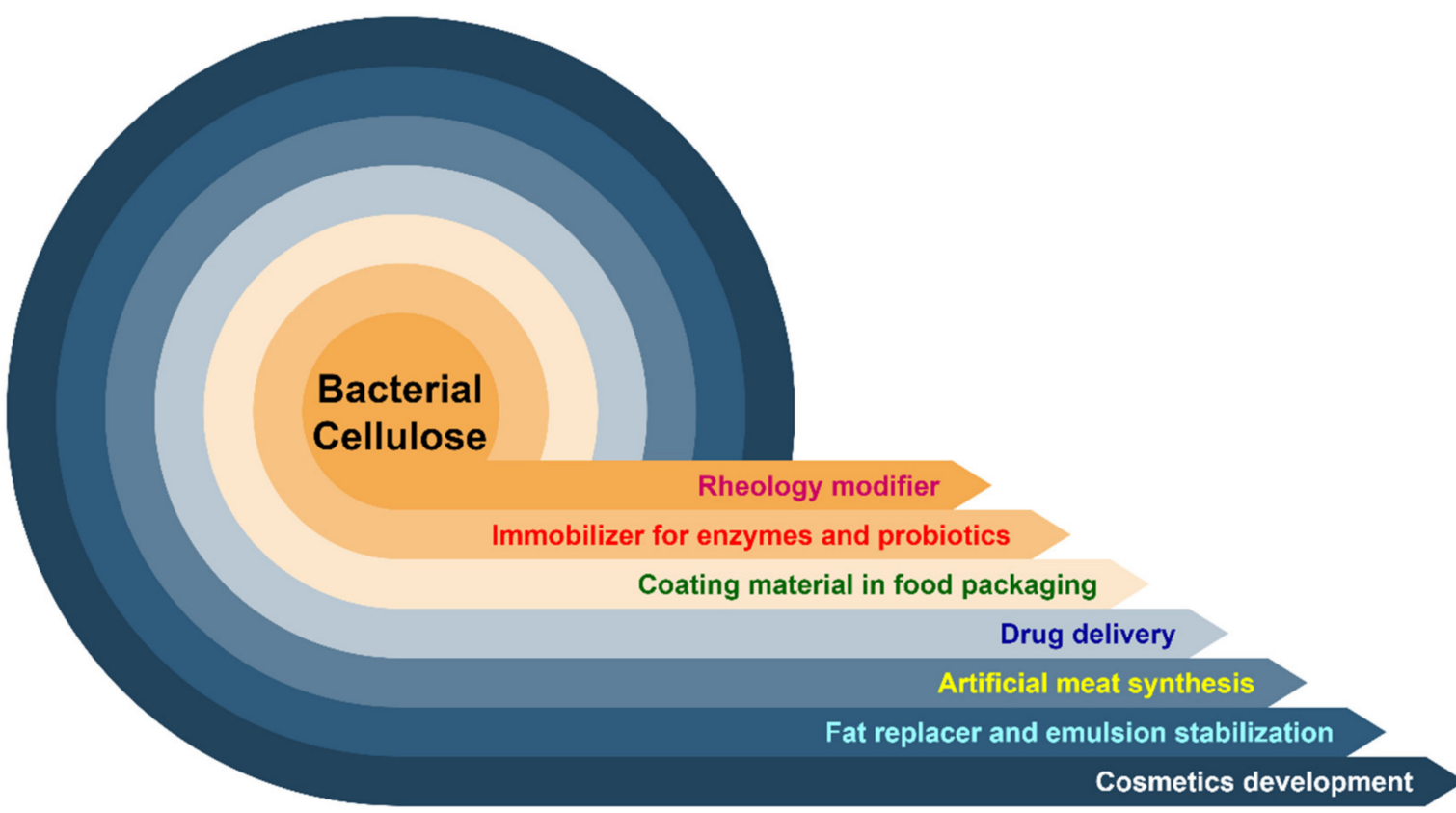

Figure 4. Applications of bacterial cellulose in different fields.

\section{Conclusions}

Bacterial cellulose, a versatile biopolymer with antimicrobial and antibiofilm efficacy, can be successfully used in therapeutic approaches. Besides its biocompatibility and biodegradability, it has numerous advantages over plant cellulose, such as purity, high water-uptake and -holding capacity, high crystallinity, high porosity and permeability to gas and liquid, and high tensile strength with mechanical robustness, which has made this natural polymer an excellent medium to be used for wound dressings, composites, dental grafts, and gels. This pure form of cellulose has zero level of toxicity and no side effects. BC biocomposites' antibiofilm efficacy has opened up a new dimension in treating biofilm-mediated chronic wounds and infections, although the only constraint is the limited productivity of $\mathrm{BC}$. The special drive is to be taken for scaling up in the production of $\mathrm{BC}$ by designing new fermenters, enduring mechanical agitation of the growing microorganisms and adopting newer biotechnological approaches to curtail the production cost by using cheap sources such as agricultural wastes or industry byproducts. Mass production of bacterial cellulose in the future will lead to the availability of a vital biomaterial that can be safely used for the production of biomedical devices, due to not only its mechanical uniqueness but also its versatile antimicrobial and antibiofilm efficacy. 
Author Contributions: Conceptualization, D.L., M.N., B.D., A.D., T.S., S.P., H.A.E., N.H.M.N. and R.R.R.; methodology, D.L., M.N., B.D., A.D., T.S., S.P., N.H.M.N., Z.A.K. and R.R.R.; formal analysis, D.L., M.N. and R.R.R.; investigation D.L., M.N. and R.R.R. writing-original draft preparation, D.L., M.N., T.S., S.P., H.A.E., N.H.M.N. and R.R.R. writing-review and editing, D.L., M.N., T.S., S.P., H.A.E., Z.A.K. and R.R.R. All authors have read and agreed to the published version of the manuscript.

Funding: No funding has been received from any funding agency to carry out the work. The financial support associated with publication of this work was supported by Universiti Sains Malaysia.

Conflicts of Interest: The authors declare no conflict of interest.

\section{References}

1. Rukmanikrishnan, B.; Ramalingam, S.; Rajasekharan, S.K.; Lee, J.; Lee, J. Binary and ternary sustainable composites of gellan gum, hydroxyethyl cellulose and lignin for food packaging applications: Biocompatibility, antioxidant activity, UV and water barrier properties. Int. J. Biol. Macromol. 2020, 153, 55-62. [CrossRef]

2. Raj, V.; Raorane, C.J.; Lee, J.-H.; Lee, J. Appraisal of Chitosan-Gum Arabic-Coated Bipolymeric Nanocarriers for Efficient Dye Removal and Eradication of the Plant Pathogen Botrytis cinerea. ACS Appl. Mater. Interfaces 2021, 13, 47354-47370. [CrossRef] [PubMed]

3. Abeer, M.M.; Mohd Amin, M.C.I.; Martin, C. A review of bacterial cellulose-based drug delivery systems: Their biochemistry, current approaches and future prospects. J. Pharm. Pharmacol. 2014, 66, 1047-1061. [CrossRef] [PubMed]

4. Ross, P.; Mayer, R.; Benziman, M. Cellulose biosynthesis and function in bacteria. Microbiol. Rev. 1991, 55, 35-58. [CrossRef]

5. Gallegos, A.M.A.; Carrera, S.H.; Parra, R.; Keshavarz, T.; Iqbal, H.M.N. Bacterial Cellulose: A Sustainable Source to Develop Value-Added Products-A Review. BioResources 2016, 11, 5641-5655. [CrossRef]

6. Sarkar, T.; Salauddin, M.; Chakraborty, R. In-depth pharmacological and nutritional properties of bael (Aegle marmelos): A critical review. J. Agric. Food Res. 2020, 2, 100081. [CrossRef]

7. Iqbal, H.M.N.; Kyazze, G.; Tron, T.; Keshavarz, T. Laccase-assisted grafting of poly(3-hydroxybutyrate) onto the bacterial cellulose as backbone polymer: Development and characterisation. Carbohydr. Polym. 2014, 113, 131-137. [CrossRef] [PubMed]

8. Iqbal, H.M.N.; Kyazze, G.; Tron, T.; Keshavarz, T. Laccase-Assisted Approach to Graft Multifunctional Materials of Interest: Keratin-EC Based Novel Composites and their Characterisation. Macromol. Mater. Eng. 2015, 300, 712-720. [CrossRef]

9. Iqbal, H.M.N.; Kyazze, G.; Locke, I.C.; Tron, T.; Keshavarz, T. In Situ development of self-defensive antibacterial biomaterials: Phenol-g-keratin-EC based bio-composites with characteristics for biomedical applications. Green Chem. 2015, 17, 3858-3869. [CrossRef]

10. Pandit, A.; Kumar, R. A Review on Production, Characterization and Application of Bacterial Cellulose and Its Biocomposites. J. Polym. Environ. 2021, 29, 2738-2755. [CrossRef]

11. Wang, J.; Tavakoli, J.; Tang, Y. Bacterial cellulose production, properties and applications with different culture methods-A review. Carbohydr. Polym. 2019, 219, 63-76. [CrossRef]

12. Sani, A.; Dahman, Y. Improvements in the production of bacterial synthesized biocellulose nanofibres using different culture methods. J. Chem. Technol. Biotechnol. 2010, 85, 151-164. [CrossRef]

13. Figueiredo, A.R.P.; Figueiredo, A.G.P.R.; Silva, N.H.C.S.; Barros-Timmons, A.; Almeida, A.; Silvestre, A.J.D.; Freire, C.S.R. Antimicrobial bacterial cellulose nanocomposites prepared by in situ polymerization of 2-aminoethyl methacrylate. Carbohydr. Polym. 2015, 123, 443-453. [CrossRef] [PubMed]

14. Förch, R.; Duque, L.; Lotz, A. 4.18-Antimicrobial Bioactive Polymer Coatings. In Comprehensive Materials Processing; Hashmi, S., Batalha, G.F., Van Tyne, C.J., Yilbas, B.B.T.-C.M.P., Eds.; Elsevier: Oxford, UK, 2014; pp. 449-461, ISBN 978-0-08-096533-8.

15. Chau, C.-F.; Yang, P.; Yu, C.-M.; Yen, G.-C. Investigation on the lipid- and cholesterol-lowering abilities of biocellulose. J. Agric. Food Chem. 2008, 56, 2291-2295. [CrossRef]

16. Czaja, W.K.; Young, D.J.; Kawecki, M.; Brown, R.M. The Future Prospects of Microbial Cellulose in Biomedical Applications. Biomacromolecules 2007, 8, 1-12. [CrossRef] [PubMed]

17. Petersen, N.; Gatenholm, P. Bacterial cellulose-based materials and medical devices: Current state and perspectives. Appl. Microbiol. Biotechnol. 2011, 91, 1277-1286. [CrossRef]

18. Pogorelova, N.; Rogachev, E.; Digel, I.; Chernigova, S.; Nardin, D. Bacterial Cellulose Nanocomposites: Morphology and Mechanical Properties. Materials 2020, 13, 2849. [CrossRef]

19. Chen, G.; Wu, G.; Alriksson, B.; Chen, L.; Wang, W.; Jönsson, L.J.; Hong, F.F. Scale-up of production of bacterial nanocellulose using submerged cultivation. J. Chem. Technol. Biotechnol. 2018, 93, 3418-3427. [CrossRef]

20. Klemm, D.; Cranston, E.D.; Fischer, D.; Gama, M.; Kedzior, S.A.; Kralisch, D.; Kramer, F.; Kondo, T.; Lindström, T.; Nietzsche, S.; et al. Nanocellulose as a natural source for groundbreaking applications in materials science: Today's state. Mater. Today 2018, 21, 720-748. [CrossRef]

21. Esa, F.; Tasirin, S.M.; Rahman, N.A. Overview of Bacterial Cellulose Production and Application. Agric. Agric. Sci. Procedia 2014, 2,113-119. [CrossRef]

22. Zhong, C. Industrial-Scale Production and Applications of Bacterial Cellulose. Front. Bioeng. Biotechnol. 2020, 8, 1425. [CrossRef] 
23. Tanaka, M.; Murakami, S.; Shinke, R.; Aoki, K. Genetic characteristics of cellulose-forming acetic acid bacteria identified phenotypically as Gluconacetobacter xylinus. Biosci. Biotechnol. Biochem. 2000, 64, 757-760. [CrossRef]

24. Keshk, S.M.A.S. Bacterial Cellulose Production and its Industrial Applications. J. Bioprocess. Biotech. 2014, 4, 1-10. [CrossRef]

25. Jonas, R.; Farah, L.F. Production and application of microbial cellulose. Polym. Degrad. Stab. 1998, 59, 101-106. [CrossRef]

26. Brown, R.M.J.; Montezinos, D. Cellulose microfibrils: Visualization of biosynthetic and orienting complexes in association with the plasma membrane. Proc. Natl. Acad. Sci. USA 1976, 73, 143-147. [CrossRef]

27. Son, H.J.; Heo, M.S.; Kim, Y.G.; Lee, S.J. Optimization of fermentation conditions for the production of bacterial cellulose by a newly isolated Acetobacter sp. A9 in shaking cultures. Biotechnol. Appl. Biochem. 2001, 33, 1-5. [CrossRef] [PubMed]

28. Matthysse, A.G.; Thomas, D.L.; White, A.R. Mechanism of cellulose synthesis in Agrobacterium tumefaciens. J. Bacteriol. 1995, 177, 1076-1081. [CrossRef] [PubMed]

29. Wang, S.-S.; Han, Y.-H.; Chen, J.-L.; Zhang, D.-C.; Shi, X.-X.; Ye, Y.-X.; Chen, D.-L.; Li, M. Insights into Bacterial Cellulose Biosynthesis from Different Carbon Sources and the Associated Biochemical Transformation Pathways in Komagataeibacter sp. W1. Polymers 2018, 10, 963. [CrossRef] [PubMed]

30. Benziman, M.; Burger-Rachamimov, H. Synthesis of cellulose from pyruvate by succinate-grown cells of Acetobacter xylinum. J. Bacteriol. 1962, 84, 625-630. [CrossRef]

31. Schramm, M.; Gromet, Z.; Hestrin, S. Synthesis of cellulose by Acetobacter xylinum. 3. Substrates and inhibitors. Biochem. J. 1957, 67, 669-679. [CrossRef] [PubMed]

32. Pang, M.; Huang, Y.; Meng, F.; Zhuang, Y.; Liu, H.; Du, M.; Ma, Q.; Wang, Q.; Chen, Z.; Chen, L.; et al. Application of bacterial cellulose in skin and bone tissue engineering. Eur. Polym. J. 2020, 122, 109365. [CrossRef]

33. Watanabe, A.; Morita, S.; Ozaki, Y. Temperature-Dependent Changes in Hydrogen Bonds in Cellulose I $\alpha$ Studied by Infrared Spectroscopy in Combination with Perturbation-Correlation Moving-Window Two-Dimensional Correlation Spectroscopy: Comparison with Cellulose I $\beta$. Biomacromolecules 2007, 8, 2969-2975. [CrossRef]

34. Watanabe, K.; Tabuchi, M.; Morinaga, Y.; Yoshinaga, F. Structural Features and Properties of Bacterial Cellulose Produced in Agitated Culture. Cellulose 1998, 5, 187-200. [CrossRef]

35. Krystynowicz, A.; Czaja, W.K.; Wiktorowska-Jezierska, A.; Gonçalves-Miśkiewicz, M.; Turkiewicz, M.; Bielecki, S. Factors affecting the yield and properties of bacterial cellulose. J. Ind. Microbiol. Biotechnol. 2002, 29, 189-195. [CrossRef] [PubMed]

36. Hestrin, S.; Schramm, M. Synthesis of cellulose by Acetobacter xylinum. II. Preparation of freeze-dried cells capable of polymerizing glucose to cellulose. Biochem. J. 1954, 58, 345-352. [CrossRef]

37. Rivas, B.; Moldes, A.B.; Domínguez, J.M.; Parajó, J.C. Development of culture media containing spent yeast cells of Debaryomyces hansenii and corn steep liquor for lactic acid production with Lactobacillus rhamnosus. Int. J. Food Microbiol. 2004, 97, 93-98. [CrossRef] [PubMed]

38. Yang, Y.; Jia, J.; Xing, J.; Chen, J.; Lu, S. Isolation and characteristics analysis of a novel high bacterial cellulose producing strain Gluconacetobacter intermedius CIs26. Carbohydr. Polym. 2013, 92, 2012-2017. [CrossRef] [PubMed]

39. Buldum, G.; Bismarck, A.; Mantalaris, A. Recombinant biosynthesis of bacterial cellulose in genetically modified Escherichia coli. Bioprocess. Biosyst. Eng. 2018, 41, 265-279. [CrossRef]

40. Velásquez-Riaño, M.; Bojacá, V. Production of bacterial cellulose from alternative low-cost substrates. Cellulose 2017, 24, 2677-2698. [CrossRef]

41. Ullah, M.W.; Ul-Islam, M.; Khan, S.; Kim, Y.; Park, J.K. Innovative production of bio-cellulose using a cell-free system derived from a single cell line. Carbohydr. Polym. 2015, 132, 286-294. [CrossRef]

42. Kim, Y.; Ullah, M.W.; Ul-Islam, M.; Khan, S.; Jang, J.H.; Park, J.K. Self-assembly of bio-cellulose nanofibrils through intermediate phase in a cell-free enzyme system. Biochem. Eng. J. 2019, 142, 135-144. [CrossRef]

43. Brown, R.M.J.; Kudlicka, K.; Cousins, S.K.; Nagy, R. Gravity effects on cellulose assembly. Am. J. Bot. 1992, 79, 1247-1258. [CrossRef]

44. De Wulf, P.; Joris, K.; Vandamme, E.J. Improved cellulose formation by an Acetobacter xylinum mutant limited in (keto)gluconate synthesis. J. Chem. Technol. Biotechnol. 1996, 67, 376-380. [CrossRef]

45. Tokoh, C.; Takabe, K.; Fujita, M.; Saiki, H. Cellulose Synthesized by Acetobacter xylinum in the Presence of Acetyl Glucomannan. Cellulose 1998, 5, 249-261. [CrossRef]

46. Ul-Islam, M.; Khan, S.; Ullah, M.W.; Park, J.K. Bacterial cellulose composites: Synthetic strategies and multiple applications in bio-medical and electro-conductive fields. Biotechnol. J. 2015, 10, 1847-1861. [CrossRef] [PubMed]

47. Lee, K.-Y.; Buldum, G.; Mantalaris, A.; Bismarck, A. More than meets the eye in bacterial cellulose: Biosynthesis, bioprocessing, and applications in advanced fiber composites. Macromol. Biosci. 2014, 14, 10-32. [CrossRef] [PubMed]

48. Yan, Z.; Chen, S.; Wang, H.; Wang, B.; Jiang, J. Biosynthesis of bacterial cellulose/multi-walled carbon nanotubes in agitated culture. Carbohydr. Polym. 2008, 74, 659-665. [CrossRef]

49. Zahan, K.A.; Hedzir, M.S.A.; Mustapha, M. The potential use of papaya juice as fermentation medium for bacterial cellulose production by Acetobacter xylinum 0416. Pertanika J. Trop. Agric. Sci. 2017, 40, 343-350.

50. Aswini, K.; Gopal, N.O.; Uthandi, S. Optimized culture conditions for bacterial cellulose production by Acetobacter senegalensis MA1. BMC Biotechnol. 2020, 20, 46. [CrossRef]

51. Rangaswamy, B.E.; Vanitha, K.P.; Hungund, B.S. Microbial Cellulose Production from Bacteria Isolated from Rotten Fruit. Int. J. Polym. Sci. 2015, 2015, 280784. [CrossRef] 
52. Zakaria, J.; Nazeri, M.A. Optimization of Bacterial Cellulose Production from Pineapple Waste: Effect of Temperature, pH and Concentration. In Proceedings of the Engineering Towards Change-Empowering Green Solutions, Sarawak, Malaysia, 10-12 July 2012; pp. 1-7.

53. Ramana, K.V.; Tomar, A.; Singh, L. Effect of various carbon and nitrogen sources on cellulose synthesis by Acetobacter xylinum. World J. Microbiol. Biotechnol. 2000, 16, 245-248. [CrossRef]

54. Matsuoka, M.; Tsuchida, T.; Matsushita, K.; Adachi, O.; Yoshinaga, F. A Synthetic Medium for Bacterial Cellulose Production by Acetobacter xylinum subsp. sucrofermentans. Biosci. Biotechnol. Biochem. 1996, 60, 575-579. [CrossRef]

55. Keshk, S.; Sameshima, K. The utilization of sugar cane molasses with/without the presence of lignosulfonate for the production of bacterial cellulose. Appl. Microbiol. Biotechnol. 2006, 72, 291-296. [CrossRef] [PubMed]

56. Bae, S.; Shoda, M. Statistical optimization of culture conditions for bacterial cellulose production using Box-Behnken design. Biotechnol. Bioeng. 2005, 90, 20-28. [CrossRef] [PubMed]

57. Kim, S.-Y.; Kim, J.-N.; Wee, Y.-J.; Park, D.-H.; Ryu, H.-W. Production of bacterial cellulose by Gluconacetobacter sp. RKY5 isolated from persimmon vinegar. Appl. Biochem. Biotechnol. 2006, 131, 705-715. [CrossRef]

58. Singhsa, P.; Narain, R.; Manuspiya, H. Physical structure variations of bacterial cellulose produced by different Komagataeibacter xylinus strains and carbon sources in static and agitated conditions. Cellulose 2018, 25, 1571-1581. [CrossRef]

59. Jung, H.-I.; Jeong, J.-H.; Lee, O.-M.; Park, G.-T.; Kim, K.-K.; Park, H.-C.; Lee, S.-M.; Kim, Y.-G.; Son, H.-J. Influence of glycerol on production and structural-physical properties of cellulose from Acetobacter sp. V6 cultured in shake flasks. Bioresour. Technol. 2010, 101, 3602-3608. [CrossRef] [PubMed]

60. Revin, V.V.; Liyas'kina, E.V.; Sapunova, N.B.; Bogatyreva, A.O. Isolation and Characterization of the Strains Producing Bacterial Cellulose. Microbiology 2020, 89, 86-95. [CrossRef]

61. Hu, W.; Chen, S.; Yang, J.; Li, Z.; Wang, H. Functionalized bacterial cellulose derivatives and nanocomposites. Carbohydr. Polym. 2014, 101, 1043-1060. [CrossRef]

62. Jung, J.Y.; Park, J.K.; Chang, H.N. Bacterial cellulose production by Gluconacetobacter hansenii in an agitated culture without living non-cellulose producing cells. Enzyme Microb. Technol. 2005, 37, 347-354. [CrossRef]

63. Hodel, K.V.; Fonseca, L.M.; Santos, I.M.; Cerqueira, J.C.; Santos-Júnior, R.E.; Nunes, S.B.; Barbosa, J.D.; Machado, B.A. Evaluation of Different Methods for Cultivating Gluconacetobacter hansenii for Bacterial Cellulose and Montmorillonite Biocomposite Production: Wound-Dressing Applications. Polymers 2020, 12, 267. [CrossRef]

64. Castro, C.; Zuluaga, R.; Putaux, J.-L.; Caro, G.; Mondragon, I.; Gañán, P. Structural characterization of bacterial cellulose produced by Gluconacetobacter swingsii sp. from Colombian agroindustrial wastes. Carbohydr. Polym. 2011, 84, 96-102. [CrossRef]

65. De Medeiros, A.D.M.; Da Silva, C.J.G., Jr.; De Amorim, J.D.P.; Do Nascimento, H.A.; Converti, A.; De Santana Costa, A.F.; Sarubbo, L.A. Biocellulose for treatment of wastewaters generated by energy consuming industries: A review. Energies 2021, $14,5066$. [CrossRef]

66. Hwang, J.W.; Yang, Y.K.; Hwang, J.K.; Pyun, Y.R.; Kim, Y.S. Effects of pH and dissolved oxygen on cellulose production by Acetobacter xylinum BRC5 in agitated culture. J. Biosci. Bioeng. 1999, 88, 183-188. [CrossRef]

67. Liu, M.; Li, S.; Xie, Y.; Jia, S.; Hou, Y.; Zou, Y.; Zhong, C. Enhanced bacterial cellulose production by Gluconacetobacter xylinus via expression of Vitreoscilla hemoglobin and oxygen tension regulation. Appl. Microbiol. Biotechnol. 2018, 102, 1155-1165. [CrossRef]

68. Molina-Ramírez, C.; Castro, M.; Osorio, M.; Torres-Taborda, M.; Gómez, B.; Zuluaga, R.; Gómez, C.; Gañán, P.; Rojas, O.J.; Castro, C. Effect of Different Carbon Sources on Bacterial Nanocellulose Production and Structure Using the Low pH Resistant Strain Komagataeibacter Medellinensis. Materials 2017, 10, 639. [CrossRef]

69. Ashori, A.; Sheykhnazari, S.; Tabarsa, T.; Shakeri, A.; Golalipour, M. Bacterial cellulose/silica nanocomposites: Preparation and characterization. Carbohydr. Polym. 2012, 90, 413-418. [CrossRef] [PubMed]

70. Sharip, N.S.; Ariffin, H. Cellulose nanofibrils for biomaterial applications. Mater. Today Proc. 2019, 16, 1959-1968. [CrossRef]

71. Mohd Amin, M.C.I.; Ahmad, N.; Halib, N.; Ahmad, I. Synthesis and characterization of thermo- and pH-responsive bacterial cellulose/acrylic acid hydrogels for drug delivery. Carbohydr. Polym. 2012, 88, 465-473. [CrossRef]

72. Dayal, M.S.; Goswami, N.; Sahai, A.; Jain, V.; Mathur, G.; Mathur, A. Effect of media components on cell growth and bacterial cellulose production from Acetobacter aceti MTCC 2623. Carbohydr. Polym. 2013, 94, 12-16. [CrossRef]

73. Li, D.; Ao, K.; Wang, Q.; Lv, P.; Wei, Q. Preparation of Pd/Bacterial Cellulose Hybrid Nanofibers for Dopamine Detection. Moleucles 2016, 21, 618. [CrossRef] [PubMed]

74. Vasconcelos, N.F.; Feitosa, J.P.A.; da Gama, F.M.P.; Morais, J.P.S.; Andrade, F.K.; de Souza, M.D.S.M.; de Freitas Rosa, M. Bacterial cellulose nanocrystals produced under different hydrolysis conditions: Properties and morphological features. Carbohydr. Polym. 2017, 155, 425-431. [CrossRef]

75. Elazzouzi-Hafraoui, S.; Nishiyama, Y.; Putaux, J.-L.; Heux, L.; Dubreuil, F.; Rochas, C. The shape and size distribution of crystalline nanoparticles prepared by acid hydrolysis of native cellulose. Biomacromolecules 2008, 9, 57-65. [CrossRef] [PubMed]

76. Bi, J.-C.; Liu, S.-X.; Li, C.-F.; Li, J.; Liu, L.-X.; Deng, J.; Yang, Y.-C. Morphology and structure characterization of bacterial celluloses produced by different strains in agitated culture. J. Appl. Microbiol. 2014, 117, 1305-1311. [CrossRef]

77. Feng, X.; Ullah, N.; Wang, X.; Sun, X.; Li, C.; Bai, Y.; Chen, L.; Li, Z. Characterization of Bacterial Cellulose by Gluconacetobacter hansenii CGMCC 3917. J. Food Sci. 2015, 80, E2217-E2227. [CrossRef] [PubMed]

78. Wang, X.; Ullah, N.; Sun, X.; Guo, Y.; Chen, L.; Li, Z.; Feng, X. Development and characterization of bacterial cellulose reinforced biocomposite films based on protein from buckwheat distiller's dried grains. Int. J. Biol. Macromol. 2017, 96, 353-360. [CrossRef] 
79. Xiang, C.; Acevedo, N.C. In Situ Self-Assembled Nanocomposites from Bacterial Cellulose Reinforced with Eletrospun Poly(lactic acid)/Lipids Nanofibers. Polymers 2017, 9, 179. [CrossRef] [PubMed]

80. Teixeira, M.A.; Paiva, M.C.; Amorim, M.T.P.; Felgueiras, H.P. Electrospun Nanocomposites Containing Cellulose and Its Derivatives Modified with Specialized Biomolecules for an Enhanced Wound Healing. Nanomaterials 2020, 10, 557. [CrossRef]

81. Fan, T.; Daniels, R. Preparation and Characterization of Electrospun Polylactic Acid (PLA) Fiber Loaded with Birch Bark Triterpene Extract for Wound Dressing. AAPS PharmSciTech 2021, 22, 205. [CrossRef]

82. Pommet, M.; Juntaro, J.; Heng, J.Y.Y.; Mantalaris, A.; Lee, A.F.; Wilson, K.; Kalinka, G.; Shaffer, M.S.P.; Bismarck, A. Surface Modification of Natural Fibers Using Bacteria: Depositing Bacterial Cellulose onto Natural Fibers To Create Hierarchical Fiber Reinforced Nanocomposites. Biomacromolecules 2008, 9, 1643-1651. [CrossRef] [PubMed]

83. Kalia, S.; Kaith, B.S.; Kaur, I. Cellulose Fibers: Bio- and Nano-Polymer Composites; Springer: Berlin/Heidelberg, Germany, 2011.

84. Fernandes, M.; Souto, A.P.; Dourado, F.; Gama, M. Application of Bacterial Cellulose in the Textile and Shoe Industry: Development of Biocomposites. Polysaccharides 2021, 2, 566-581. [CrossRef]

85. Yu, K.; Aubin-Tam, M.-E. Bacterially Grown Cellulose/Graphene Oxide Composites Infused with $\gamma$-Poly (Glutamic Acid) as Biodegradable Structural Materials with Enhanced Toughness. ACS Appl. Nano Mater. 2020, 3, 12055-12063. [CrossRef]

86. Zhang, P.; Chen, L.; Zhang, Q.; Hong, F.F. Using In Situ Dynamic Cultures to Rapidly Biofabricate Fabric-Reinforced Composites of Chitosan/Bacterial Nanocellulose for Antibacterial Wound Dressings. Front. Microbiol. 2016, 7, 260. [CrossRef] [PubMed]

87. Kołodziejska, M.; Jankowska, K.; Klak, M.; Wszoła, M. Chitosan as an Underrated Polymer in Modern Tissue Engineering. Nanomaterials 2021, 11, 3019. [CrossRef]

88. Savitskaya, I.; Kistaubayeva, A.; Digel, I.; Shokatayeva, D. Physicochemical and Antibacterial Properties of Composite Films Based on Bacterial Cellulose and Chitosan for Wound Dressing Materials. Eurasian Chem. J. 2017, 19. [CrossRef]

89. Cabañas-Romero, L.V.; Valls, C.; Valenzuela, S.V.; Roncero, M.B.; Pastor, F.I.J.; Diaz, P.; Martínez, J. Bacterial Cellulose-Chitosan Paper with Antimicrobial and Antioxidant Activities. Biomacromolecules 2020, 21, 1568-1577. [CrossRef] [PubMed]

90. Ostadhossein, F.; Mahmoudi, N.; Morales-Cid, G.; Tamjid, E.; Navas-Martos, F.J.; Soriano-Cuadrado, B.; Paniza, J.M.L.; Simchi, A. Development of Chitosan/Bacterial Cellulose Composite Films Containing Nanodiamonds as a Potential Flexible Platform for Wound Dressing. Materials 2015, 8, 6401-6418. [CrossRef] [PubMed]

91. Abral, H.; Pratama, A.B.; Handayani, D.; Mahardika, M.; Aminah, I.; Sandrawati, N.; Sugiarti, E.; Muslimin, A.N.; Sapuan, S.M.; Ilyas, R.A. Antimicrobial Edible Film Prepared from Bacterial Cellulose Nanofibers/Starch/Chitosan for a Food Packaging Alternative. Int. J. Polym. Sci. 2021, 2021, 6641284. [CrossRef]

92. Laromaine, A.; Tronser, T.; Pini, I.; Parets, S.; Levkin, P.A.; Roig, A. Free-standing three-dimensional hollow bacterial cellulose structures with controlled geometry via patterned superhydrophobic-hydrophilic surfaces. Soft Matter 2018, 14, $3955-3962$. [CrossRef] [PubMed]

93. Ul-Islam, M.; Khan, T.; Khattak, W.A.; Park, J.K. Bacterial cellulose-MMTs nanoreinforced composite films: Novel wound dressing material with antibacterial properties. Cellulose 2013, 20, 589-596. [CrossRef]

94. Pinto, R.J.B.; Daina, S.; Sadocco, P.; Neto, C.P.; Trindade, T. Antibacterial Activity of Nanocomposites of Copper and Cellulose. Biomed. Res. Int. 2013, 2013, 280512. [CrossRef]

95. Xie, Y.-Y.; Hu, X.-H.; Zhang, Y.-W.; Wahid, F.; Chu, L.-Q.; Jia, S.-R.; Zhong, C. Development and antibacterial activities of bacterial cellulose/graphene oxide-CuO nanocomposite films. Carbohydr. Polym. 2020, 229, 115456. [CrossRef] [PubMed]

96. Wahid, F.; Duan, Y.-X.; Hu, X.-H.; Chu, L.-Q.; Jia, S.-R.; Cui, J.-D.; Zhong, C. A facile construction of bacterial cellulose/ZnO nanocomposite films and their photocatalytic and antibacterial properties. Int. J. Biol. Macromol. 2019, 132, 692-700. [CrossRef]

97. Yang, M.; Ward, J.; Choy, K.-L. Nature-Inspired Bacterial Cellulose/Methylglyoxal (BC/MGO) Nanocomposite for BroadSpectrum Antimicrobial Wound Dressing. Macromol. Biosci. 2020, 20, 2000070. [CrossRef]

98. De Mattos, I.B.; Nischwitz, S.P.; Tuca, A.-C.; Groeber-Becker, F.; Funk, M.; Birngruber, T.; Mautner, S.I.; Kamolz, L.-P.; Holzer, J.C.J. Delivery of antiseptic solutions by a bacterial cellulose wound dressing: Uptake, release and antibacterial efficacy of octenidine and povidone-iodine. Burns 2020, 46, 918-927. [CrossRef]

99. Yaşayan, G.; Karaca, G.; Akgüner, Z.P.; Öztürk, A.B. Chitosan/collagen composite films as wound dressings encapsulating allantoin and lidocaine hydrochloride. Int. J. Polym. Mater. Polym. Biomater. 2021, 70, 623-635. [CrossRef]

100. Beekmann, U.; Schmölz, L.; Lorkowski, S.; Werz, O.; Thamm, J.; Fischer, D.; Kralisch, D. Process control and scale-up of modified bacterial cellulose production for tailor-made anti-inflammatory drug delivery systems. Carbohydr. Polym. 2020, $236,116062$. [CrossRef] [PubMed]

101. Lahiri, D.; Dash, S.; Dutta, R.; Nag, M. Elucidating the effect of anti-biofilm activity of bioactive compounds extracted from plants. J. Biosci. 2019, 44, 52. [CrossRef] [PubMed]

102. Ghosh, S.; Lahiri, D.; Nag, M.; Dey, A.; Sarkar, T.; Pathak, S.K.; Edinur, H.A.; Pati, S.; Ray, R.R. Bacterial biopolymer: Its role in pathogenesis to effective biomaterials. Polymers 2021, 13, 1242. [CrossRef]

103. Lahiri, D.; Nag, M.; Ghosh, A.; Dey, A.; Mukherjee, D.; Garai, S.; Ray, R.R. Biofilm and Antimicrobial Resistance. In Biofilm-Mediated Diseases: Causes and Controls; Ray, R.R., Nag, M., Lahiri, D., Eds.; Springer: Singapore, 2021; pp. 183-208.

104. Clinton, A.; Carter, T. Chronic Wound Biofilms: Pathogenesis and Potential Therapies. Lab. Med. 2015, 46, 277-284. [CrossRef]

105. Lee, J.-H.; Park, J.-H.; Cho, H.S.; Joo, S.W.; Cho, M.H.; Lee, J. Anti-biofilm activities of quercetin and tannic acid against Staphylococcus aureus. Biofouling 2013, 29, 491-499. [CrossRef] 
106. Siddiqui, M.F.; Oh, H.-S.; Rzechowicz, M.; Winters, H.; Chong, T.H.; Fane, A.G. Biofouling control potential of tannic acid, ellagic acid, and epigallocatechin against Pseudomonas aeruginosa and reverse osmosis membrane multispecies community. J. Ind. Eng. Chem. 2015, 30, 204-211. [CrossRef]

107. Luo, J.; Lai, J.; Zhang, N.; Liu, Y.; Liu, R.; Liu, X. Tannic Acid Induced Self-Assembly of Three-Dimensional Graphene with Good Adsorption and Antibacterial Properties. ACS Sustain. Chem. Eng. 2016, 4, 1404-1413. [CrossRef]

108. Barud, H.S.; Barrios, C.; Regiani, T.; Marques, R.F.C.; Verelst, M.; Dexpert-Ghys, J.; Messaddeq, Y.; Ribeiro, S.J.L. Self-supported silver nanoparticles containing bacterial cellulose membranes. Mater. Sci. Eng. C 2008, 28, 515-518. [CrossRef]

109. Pinto, R.J.B.; Marques, P.A.A.P.; Neto, C.P.; Trindade, T.; Daina, S.; Sadocco, P. Antibacterial activity of nanocomposites of silver and bacterial or vegetable cellulosic fibers. Acta Biomater. 2009, 5, 2279-2289. [CrossRef]

110. Morones, J.R.; Elechiguerra, J.L.; Camacho, A.; Holt, K.; Kouri, J.B.; Ramírez, J.T.; Yacaman, M.J. The bactericidal effect of silver nanoparticles. Nanotechnology 2005, 16, 2346-2353. [CrossRef]

111. Nagy, A.; Harrison, A.; Sabbani, S.; Munson, R.S.J.; Dutta, P.K.; Waldman, W.J. Silver nanoparticles embedded in zeolite membranes: Release of silver ions and mechanism of antibacterial action. Int. J. Nanomed. 2011, 6, 1833-1852. [CrossRef]

112. Divya, K.; Vijayan, S.; George, T.K.; Jisha, M.S. Antimicrobial properties of chitosan nanoparticles: Mode of action and factors affecting activity. Fibers Polym. 2017, 18, 221-230. [CrossRef]

113. Pati, S.; Chatterji, A.; Dash, B.P.; Nelson, B.R.; Sarkar, T.; Shahimi, S.; Edinur, H.A.; Abd Manan, T.S.B.; Jena, P.; Mohanta, Y.K.; et al. Structural characterization and antioxidant potential of chitosan by $\gamma$-irradiation from the carapace of horseshoe crab. Polymers 2020, 12, 2361. [CrossRef]

114. Pati, S.; Sarkar, T.; Sheikh, H.I.; Bharadwaj, K.K.; Mohapatra, P.K.; Chatterji, A.; Dash, B.P.; Edinur, H.A.; Nelson, B.R. $\gamma$-Irradiated Chitosan from Carcinoscorpius rotundicauda (Latreille, 1802) Improves the Shelf Life of Refrigerated Aquatic Products. Front. Mar. Sci. 2021, 8, 498. [CrossRef]

115. Kong, M.; Chen, X.G.; Xing, K.; Park, H.J. Antimicrobial properties of chitosan and mode of action: A state of the art review. Int. J. Food Microbiol. 2010, 144, 51-63. [CrossRef] [PubMed]

116. Jeon, Y.-J.; Park, P.-J.; Kim, S.-K. Antimicrobial effect of chitooligosaccharides produced by bioreactor. Carbohydr. Polym. 2001, 44, 71-76. [CrossRef]

117. Darabpour, E.; Kashef, N.; Mashayekhan, S. Chitosan nanoparticles enhance the efficiency of methylene blue-mediated antimicrobial photodynamic inactivation of bacterial biofilms: An in vitro study. Photodiagn. Photodyn. Ther. 2016, 14, 211-217. [CrossRef]

118. Chen, X.; Cui, J.; Xu, X.; Sun, B.; Zhang, L.; Dong, W.; Chen, C.; Sun, D. Bacterial cellulose/attapulgite magnetic composites as an efficient adsorbent for heavy metal ions and dye treatment. Carbohydr. Polym. 2020, 229, 115512. [CrossRef]

119. Song, S.; Liu, Z.; Zhang, J.; Jiao, C.; Ding, L.; Yang, S. Synthesis and Adsorption Properties of Novel Bacterial Cellulose/Graphene Oxide/Attapulgite Materials for $\mathrm{Cu}$ and Pb Ions in Aqueous Solutions. Materials 2020, 13, 3703. [CrossRef] [PubMed] 